\section{Risk of cross-infection related to the multiple use of disposable syringes}

Claude A. Trépanier MD FRCPC, Martin R. Lessard MD, Jacques G. Brochu MD FRCPC, Pierre H. Denault MD FRCPC
The rate of blood contamination of IV tubings used in anaesthesia practice was investigated. Only $I V$ tubings started in the operating room were studied. First, 300 tubings of three different types were tested at the three distal injection sites. The contamination rate was 3.3 per cent at the injection site closest to the IV catheter and 0.3 per cent at the furthest. The presence of a check-valve did not affect the contamination rate. Second, 300 third injection sites fixed at a level equal to or above the IV catheter were tested. None of them was contaminated. Finally, in order to evaluate whether changing the needle alone could prevent the contamination of syringes, injections were made into a tubing where blood was flowing. Thirty-four per cent of the syringes tested positive for blood. We conclude that IV tubings have a significant contamination rate in usual practice. This rate decreases as the distance from the IV catheter increases. The use of the third site fired at a level equal to or above the IV catheter carries a lower risk of contamination. Changing the needle alone is a useless procedure to prevent crosscontamination.

Le taux de contamination sanguine des tubulures des intraveineuses installées en salle d'opération a été étudié. Premièrement, 300 tubulures ont été testées au trois premiers sites d'injection. La présence de sang a été détectée dans 3.3 pour cent des sites d'injection proximaux et dans seulement 0.3 pour cent des sites distaux. La présence d'une valve anti-reflux n'a pas modifié l'incidence de contamination. Dans un deuxième

\section{Key words}

COMPLICATIONS: infections;

EQUIPMENT: infusion systems, needles, syringes; INFECTION: acquired immune deficiency syndrome; OPERATING ROOMS: contamination.

From the Département d'Anesthésie, Hôpital de l'Enfant-Jésus, Université Laval, Québec.

Presented at the Journées Franco-Québeccoises d'AnesthésieRéanimation, Montréal, May 1989.

Address correspondence to: Dr C. Trépanier, Département d'anesthésie, Hôpital de l'Enfant-Jésus, 1401, 18e rue, Québec, GIJ 1 Z4. temps, on a recherché la présence de sang au troisième site d'injection de 300 tubulures fixées à un niveau égal ou supérieur au cathéter veineux. Aucun de ces sites n'était contaminé. Finalement, l' efficacité de la pratique de changer seulement les aiguilles pour prévenir la contamination des seringues a été vérifiée. Trente-quatre pour cent des seringues testées étaient contaminées. En conclusion, le taux de contamination sanguine des tubulures est significatif dans la pratique anesthésique quotidienne. Ce taux diminue en s'éloignant du cathéter veineux. L'utilisation du troisième site d'injection, fixé à un niveau égal ou supérieur au cathéter veineux, comporte un risque inférieur de contamination. Enfin, changer uniquement les aiguilles est une pratique inutile pour prévenir la contamina tion des seringues.

The practice of reusing disposable plastic syringes for several injections to different patients is still prevalent in North American operating rooms despite warnings about its possible hazards. ${ }^{1-3}$ One study suggested that this practice does not increase the incidence of bacterial contamination of needles and syringes. ${ }^{4}$ However, the risk of viral cross-infection from a syringe contaminated by blood refluxing in the IV tubing has not been well documented. The only studies we could find were two abstracts which reported that some tubings were indeed contaminated by blood. ${ }^{5,6}$ However, in these studies, the two main factors involved in the occurence of contamination were prior transfusion of blood and the use of infusion sets that had been started on the ward before surgery. This study was designed to evaluate the rate of blood contamination of IV tubings in anaesthesia and to estimate the risk of cross-infection associated with the multiple use of disposable syringes.

\section{Methods}

The protocol was approved by the Hospital Ethics Committee. After testing several methods of detecting blood in IV fluid, the following technique was selected. Blood detection was carried out with the Ames Multistix ${ }^{\oplus}$ which was automatically read by the Clinitek $200^{\circledR}$ Module. The sample to be tested was dropped on the 
TABLE I Drug and IV fluids tested

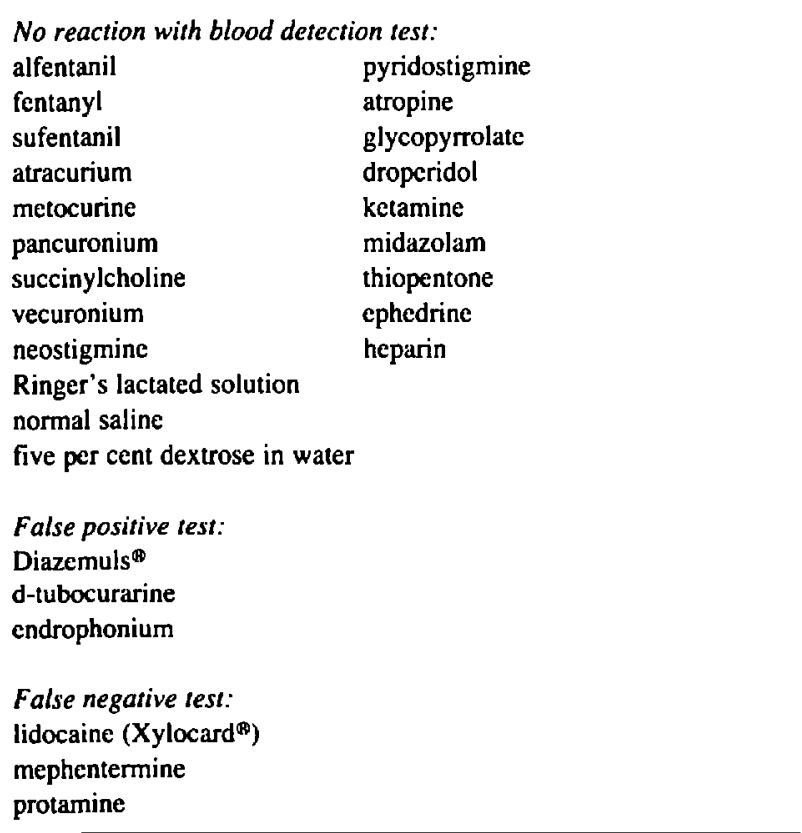

reagent strip which was then processed by the reading module. This method of blood detection is based on the peroxydase-like activity of haemoglobin. The sensitivity of the method was tested by serial dilution and was constantly reliable up to dilutions of $1 / 32,000$. Also the specificity of the technique was verified by testing the drugs and IV solutions commonly used in anaesthesia (Table I). D-tubocurarine, Diazemuls ${ }^{\circledR}$ and edrophonium gave false positive results. Similarly, these drugs were tested for their ability to nullify a positive result which is characteristic of protamine, mephentermine and lidocaine. All tubings that had been exposed to one of these six drugs were excluded from the study.

The study was conducted in three parts. In the first, 300 IV tubings of three different types were tested for the presence of blood: the Baxter JC 5417 without a checkvalve, the Abbott Venoset 5742 and the Baxter JC 5537, the latter two with a check valve. A Baxter JC 0058 extension tubing with two injection sites was added to all tubings. Tubings were randomly assigned to patients undergoing surgery. All the IV infusions were started in the operating room before anaesthesia, which proceeded as usual. After surgery, in the recovery room, fluid was sampled from the three injection sites closest to the IV catheter. The tubings were clamped both upstream and downstream, and $0.2 \mathrm{ml}$ of fluid was aspirated in a Vacutainer ${ }^{\$}$ blood collection tube. All the tubings that had been used to transfuse blood or that had been set up on the same arm as the blood pressure cuff were excluded.

In the second part, 300 Baxter JC 5537 IV tubings with Baxter JC 0058 extension tubings were tested. The third injection site from the IV catheter was studied and it was carefully taped to the operating table at a level equal to or above the IV catheter as soon as the infusion had been started. After surgery, but before the patient left the operating room, the injection site was sampled and tested for the presence of blood.

In the third part, the practice of changing the needle while reusing the same syringe was tested. One hundred 5 $\mathrm{ml}$ syringes with 20-gauge needles were filled with normal saline. Three $\mathrm{ml}$ were then injected through the injection site of a tubing connected to a unit of blood running at maximum flow through a 16-gauge needle. The 20-gauge needle was then removed from the syringe and replaced. The remaining fluid in the syringe was tested for blood. Statistical analysis was performed using 95 per cent confidence limits, ANOVA, and Chi-Square test when appropriate.

\section{Results}

Contamination rates and intervals between IV catheterisation and sampling in part one of the study are presented in Table II. The global contamination rate was 3.33 per cent ( 95 per cent confidence limits 2.26-4.73). Only 33 per cent of the contaminated tubings were recognized by visual observation. There was no difference among the three types of tubings used. Only one of the third injection sites (furthest from IV catheter) was contaminated. This 0.3 per cent $(0.01-1.84)$ incidence was lower than at the first site $(P<0.05)$. There was no statistically significant difference between the different tubings. In part two, none of the 300 IV tubings tested positive for blood (0.00-1.22). Mean interval between IV catheterisation and sampling was $75.5 \pm 42.5$ minutes. In part three, 34 per cent (24.8-44.1) of the syringes studied tested positive for the presence of blood.

\section{Discussion}

Despite wamings, multiple use of disposable syringes is still a common practice in North America. ${ }^{1-3}$ The paucity of objective data on syringe contamination by blood, combined with the absence of reports of viral disease transmission by this route may partly explain the reluc-

TABLE II Contaminated tubings

\begin{tabular}{llll}
\hline & $\begin{array}{l}\text { Baxter JC 5417 } \\
n=103\end{array}$ & $\begin{array}{l}\text { Baxter JC 5537 } \\
n=98\end{array}$ & $\begin{array}{l}\text { Abbout } 5742 \\
n=99\end{array}$ \\
\hline $\begin{array}{l}\text { Injection site } \\
- \text { First }\end{array}$ & $4(1)$ & $3(1)$ & \\
- Second & $1(0)$ & $2(1)$ & $3(2)$ \\
- Third & $0(0)$ & $1(0)$ & $1(0)$ \\
Interval (min) & $112.1 \pm 52.3$ & $124.3 \pm 63.7$ & $0(0)$ \\
\hline
\end{tabular}

Reagent strip (visual) detection. 
tance of anaesthetists to change syringes after each case. Other possible contributing factors are the cost inherent in such a policy and the cumbersome task of preparing a new set of syringes for every case.

Objective data should be available to evaluate the risks related to that practice. The ultimate goal of such a study would be to determine the incidence of cross-infection in surgical patients. However, proving that even a single patient has been infected by these means requires exclusion of all other possible causes. We elected to test IV tubings for the presence of blood that would have the potential to contaminate syringes. The risk of crossinfection related to that practice can then be estimated. The data show that the IV tubings handled in the usual manner have a contamination rate of 3.33 per cent at the first injection site, but that only one third of these could be recognized by visual observation. Many anaesthetists prefer to use the first injection site because of its faster access to the circulation. These data show that even IV tubings started in the operating room have a significant rate of blood contamination at this site. However, only one of the $\mathbf{3 0 0}$ third sites tested was contaminated, which means that the constant use of this site carries a lower potential risk of contaminating syringes.

A surprising finding was the absence of a difference in the frequency of contamination between the three different types of IV tubings. The presence of a check valve makes no difference in incidence of contamination. The check valve closing pressures of the two brands used were measured and both were efficient in preventing reflux, closing at a trans-valvular pressure less than $1 \mathrm{mmHg}$. This suggests that contamination occurs by another mechanism than through reflux by a pressure gradient. This may occur because blood, having a specific gravity of $1.06,{ }^{7}$ will sediment if the distal tubing is allowed to hang at the side of the operating table in a position lower than the IV catheter, therefore contaminating the injection sites that are in a dependent position. A high flow rate in the tubing may prevent this phenomenom. However, we did not make any attempt to alter the flow rates that anaesthetists used during the study.

The first part of this study demonstrated that the reuse of syringes in the clinical setting is a potential hazard. In the second part, we attempted to control the two main factors having the potential to promote blood contamination, i.e., distance from the IV catheter to the injection site and their relative heights. Controlling these two factors, none of the 300 sites tested was contaminated. However, the sample size only allowed to conclude with 95 per cent confidence that the contamination rate was no higher than 1.22 per cent.

The risk of transmission of the human immunodeficiency virus (HIV) or the hepatitis B virus (HBV) associated with the practice of reusing syringes in these conditions can be estimated from published data. The reported prevalence of HIV seropositives in Canada varies from 0.01 to 0.016 per cent ${ }^{8-10}$ Multiplying the highest figure by the seroconversion rate after accidental parenteral exposure to HIV, 0.4 per cent ${ }^{11}$ and by the upper confidence limit of our data on tubing contamination rate $(<1.22$ per cent), the risk of contaminating a patient with HIV is no more than $1 / 128,000,000$. Making the same calculation with $\mathrm{HBV}$, (prevalence $=0.1$ to 0.5 per cent, $^{12-14}$ seroconversion rate $=5$ percent ${ }^{15}$ ) the risk is no higher than $1 / 328,000$. According to the data from the first part of this study, these risks would be increased approximately ten times if the first injection site were to be used. The prevalence data used in these calculations are taken from the Canadian Department of Health and Welfare statistics. It is well known that both HIV and $\mathrm{HBV}$ prevalences have a large geographical variability. In some areas with a higher prevalence of these viruses, the risk associated with reuse of syringes would obviously be higher. It is interesting to note that although AIDS started the debate on the risk of reusing syringes, hepatitis $B$ has a much higher risk of being transmitted and was probably contaminating syringes long before AIDS was even known. Previous studies have shown that the risk of blood contamination is increased in certain conditions: "old IVs," previous transfusions and ipsilateral blood pressure cuff. ${ }^{5.6}$ The risks calculated above surely underestimate the contamination potential in these circumstances.

In some operating rooms, the usual practice is to reuse disposable syringes while changing the needles. This practice is based on the assumption that, since only the needle enters the injection site, it is the only part that can be contaminated. The third part of this study was designed to evaluate this practice. To increase the sensitivity of the blood detection test, injections were made directly into a stream of blood. The set-up used reproduced the pressure and flow conditions normally encountered during the usual clinical setting. The results are compatible with those reported with intradermal syringes. ${ }^{16} \mathrm{~A}$ high proportion of the syringes was contaminated, even if only the needle had been in contact with blood. The probable mechanism of contamination is by aspiration into the syringe of the blood remaining inside the needle because of the negative pressure generated when removing the needle. This high rate of contamination emphasizes the uselessness of this practice to prevent syringe contamination.

The safest policy is to change all syringes after each case. However, this practice carries a high cost because of the price of many new drugs that would be discarded with the syringes. The real cost associated with such a policy is difficult to estimate because of the variability in both the 
nature and the amount of drugs remaining in syringes at the end of a case. However, this should be taken into account when estimating the cost-effectiveness of any policy on the reuse of syringes.

In conclusion, in routine use, IV tubings started in the operating room have a significant rate of blood contamination. This rate decreases as the distance from the IV catheter increases. The use of the third site fixed at a level equal to or above the IV catheter carries a lower risk of contamination and cross-infection. Finally, changing only the needle is of no value in preventing cross-contamination of patients.

\section{Acknowledgements}

The authors thank Dr. Claude A. Tremblay for her expertise in reviewing the manuscript, Dr. Gilles Turcotte for technical assistance, Mrs. Suzanne B. Koenig for secretarial assistance and the Abbott company who supplied the tubings used in the investigation.

\section{References}

1 Recommendations for prevention of HIV transmission in health care settings. MMWR 1987; 36: 2 S.

2 Browne RA, Chernesky MA. Infectious diseases and the anaesthetist. Can J Anaesth 1988; 35: 655-65.

3 Heseltine $P$. Anesthesiologists should not give IV medications with common syringe. Hospital Infection Control 1986; 13: 84-5.

4 Lessard MR, Trépanier CA, Gourdeau M, Denault PH. A microbiological study of the contamination of the syringes used in anacsthesia practice. Can J Anaesth 1988; 35: 567-9.

5 Hein HAT, Reinhardt RD, Wansbourgh SR, Jantzen $J \cdot P A H$, Giesecke $A H$. Recapping needles in anesthesia - is it safe? Anesthesiology 1987; 67: A161.

6 Parlow $J L$. Blood contamination of drug syringes used in anaesthesia. Can J Anaesth 1989; 36: S61-2.

7 Diem K, Lentner C. Scientific Tables. 7th ed. Basle: Geigy, 1970: 557.

8 HIV-1 infections in the Canadian atlantic provinces. Canada Diseases Weekly Report 1988; 14: 107-9.

9 Laboratory evidence of human immunodeficiency virus-one infection in Canada 1986. Canada Diseases Weekly Report 1987; 13: 147-8.

10 Serodiagnosis of HIV in Manitoba. Canada Diseases Weekly Report 1988; 14: 5-7.

11 Becker CE, Cowe JE, Gerberding J. Occupational infection with human immunodeficiency virus (HIV). Ann Intern Med 1989; 110: 653-6.

12 Universal prenatal screening for hepatitis B, Alberta 1985-1988. Canada Diseases Weekly Report 1989; 15: 29-32.
13 Hepatitis B infection in Canada. Canada Diseases Weekly Report, 1985; 11: 1-4.

14 Kumar ML, Dawson NV, McCullough AJ. Should all pregnant women be screened for hepatitis B? Ann Intern Med 1987; 107: 273-7.

15 Immune globulins for protection against viral hepatitis: recommendations of the immunization practice advisory committee (ACIP). MMWR 1981; 30: 423-35.

16 Lutz CT, Bell CE, Wedner HJ, Krogstad DJ. Allergy testing of multiple patients should no longer be performed with a common syringe. $N$ Engl J Med 1984; 310 : 1335-7. 